\title{
Sorcery and Science: Honoring the Work of Shirley Lindenbaum
}

\author{
Atwood D. Gaines ${ }^{1}$
}

Published online: 1 November 2017

(C) Springer Science+Business Media, LLC 2017

Culture, Medicine and Psychiatry is pleased to honor Professor Shirley Lindenbaum in this volume year (2017). In each number of the year, we noted that she was this year's honoree and, in this, the final number of the volume, we provide a summary of her work and career. This summary includes her publications for readers interested in pursuing subjects and topics of interest to them and that appear in Professor Lindenbaum's bibliography.

We begin the survey of Professor Lindenbaum's work and career that includes her education, academic positions and service. We then move on to a consideration of her research, which, as should be well-known, includes her work on Kuru among the Fore of New Guinea and the role of that research in the discovery of a completely new pathogen, the prion, and her work illuminating the social nature of epidemics of prion diseases and of AIDS.

\section{Education}

Professor Lindenbaum was educated in her native Australia, taking her BA from the University of Melbourne in 1955. She later received her MA from the University of Sydney in 1971 and her PhD Waiver from the City University of New York's Academic Standards Committee the following year. She was awarded an Honorary doctorate, a Doctor of Letters, from her Alma Mater in 2016.

Atwood D. Gaines

atwood.gaines@case.edu

1 Case Western Reserve University, Cleveland, OH, USA 


\section{Academic Career}

Professor Lindenbaum took up her first academic position in 1972 as an assistant professor of Anthropology in the York College of the City University of New York, where she remained until 1976. The following year, she was called to a position as assistant professor of Anthropology in the Graduate Faculty of the New School for Social Research in New York. She earned tenure in 1981 and assumed the position of Associate Professor of Anthropology of the Graduate Faculty of the New School where she remained until 1989 when she moved to take up the post Professor of Anthropology in the Graduate Program in Anthropology at the City University of New York. From 1994 through 1997, Professor Lindenbaum served as the Executive Officer (Chair) of the Graduate Program in Anthropology at the City University. She retired from CUNY in 2009 after some 20 years there. She was granted emerita status upon her retirement in 2009.

\section{Professional Service}

In her career, she has been or remains a member of a number of prestigious organizations and committees. Her service to the discipline of anthropology and to health organizations is laudable and much appreciated by the various entities she served. These include the Wenner-Gren Advisory Council, as Board Member (1996-2000), the National Academy of Sciences' Committee on AIDS Research (1987-1994), the American Anthropological Association Commission on AIDS (1993-1998), which she chaired. She served also on the Commission on Publications Policy of the American Anthropological Association (1992-1993) and was a member of the Technical Advisory Group of Family Health International, AIDS Control and Prevention Project (1992-1997), and as well as of the International Child Health Foundation (1985-1995). With the National Science Foundation, Professor Lindenbaum served on the Advisory Panel in Social and Cultural Anthropology from 1983 to 1985.

She was President of the Society for Medical Anthropology (1989-1991) as well as of the Metropolitan Medical Anthropology Association (New York) for 13 years beginning in 1987. In 2014, after her retirement, Professor Lindenbaum served on the Expert Advisory Committee of the New York Academy of Medicine Center for the History of Medicine and Public Health (2014).

Professor Lindenbaum's service to the discipline and beyond includes her work as Editor of the American Ethnologist (1984-1989) and serving as the Associate Editor of Medical Anthropology (1986-2001). She continues her work with Medical Anthropology through her membership on the editorial boards of Culture, Medicine and Psychiatry, Medicine Anthropology Theory and Anthropology Now (2010-2013).

She has also served on the Editorial Board of several important book series including Annual Review of Anthropology (1997-2000), Cambridge Publications in 
Medical Anthropology, 1999 to 2004, and on the Advisory Board of the Rutgers University Press Studies in Medical Anthropology (2005 to present).

Professor Lindenbaum has also delivered a number of Distinguished Lectures, at NYU, Oxford, the Wenner-Gren Foundation and the American Museum of Natural History. She has also been honored with an AES panel honoring her. And she has participated in a number of Wenner-Gren Foundation for Anthropological Research International Symposia around the world, in Bellagio, Italy, New York, Santa Fe, NM, Spain, Portugal, and Mexico as well as a number of other sites in the US.

\section{Fieldwork and Research: Sorcery and Science}

Professor Lindenbaum is best known for her work among the Fore of New Guinea and for her work on AIDS in New York. Her work has been funded by the Rockefeller Foundation (her first work among the Fore) as well as a variety of Papua New Guinea Institutes and departments. Her work in Bangladesh was funded by that country's laboratories and ministries as well as the Ford Foundation. She has also received funding from the Wenner-Gren Foundation.

For several years, 1961-1963, Professor Lindenbaum did research among the Fore of the Eastern Highlands of New Guinea targeting the local affliction known as Kuru which, in biomedical terms, was described as a progressive, fatal disorder (1963, 1972, 1979a, c). Her original funding from the Rockefeller Foundation for this research specifically suggested that she target genealogies to discern the assumed genetic cause of kuru.

However, her research revealed that the Fore create their kinship through horizontal kin ties, not vertical descent, thus showing kuru was not some autosomal dominant genetic disorder, a disorder with a $100 \%$ case fatality rate $(1971,1972)$. For the Fore, Kuru was the result of sorcery (1976b, c, d, 1979a, b, c). As Lindenbaum worked on kuru, she also worked on the various narratives and counter narratives of researchers and non-academic/medical writers (see 2001, 2015). While a complicated history, Lindenbaum gives us not only a detailed reading of the Fore and the impact of kuru on them, and their view of it as a result of sorcery and which, hence, guided their response to it $(1964,1971,1975,1981 b)$, but also of the various medical constructions of the disorder that began in 1957. Interestingly, there then (1970s) continued to be "an abundance of hypotheses-infectious etiology, possible plant toxins, metallic poisoning.... and (even) a return to the genetic constitution of the kuru-affected populations" (2001:368-369).

Such hypotheses were aimed at discounting the sociocultural suggestions from Lindenbaum that implicated mortuary cannibalism and gender roles (1968 w/Mathews and RM Glasse; 1977) as the means for the spread of the disease (1982). It was not until 1974 that the "classical trio" was established, that of kuru, scrapie and classical Creutzfeldt-Jakob Disease (Lindenbaum 2001: 369; see also 2015). And, it was not until 1972 that Prusiner found, purified and named the infectious proteinaceous agent for scrapie and similar diseases, i.e., "prion" caused diseases (Prusiner 1972). 
Lindenbaum wisely took from these debates, in which her research was regularly discounted (without basis) by biomedical researchers, lessons on epidemics as well as the construction of clinical reality and authority in Biomedicine (2001, 2015, 2017). Her work suggests that epidemics, like that of kuru among the Fore, are, like the theories that explain them, tied to particular social forms (2001:371). As well, there are issues of turf, e.g., seemingly genetic diseases can only be explained by medical researchers, not social scientists. Detailed analyses of contrasting and conflicting narratives are to be found in Lindenbaum's own work (see especially, 2001, 2015 and 2017).

Lindenbaum went on to consider a variety of epidemics and the structure and social contexts of those epidemics of other prion diseases such as BSE (Bovine Spongiform Encephalopathy) and vCJD (variant Cruetzfeld-Jakob Disease) and of AIDS (Herdt and Lindenbaum 1992). In these works, she paid close attention to the stage-like unfolding of epidemics (after Rosenberg 1992, see also Rosenberg and Golden 1997) and their nature as social phenomena with similar dramaturgical forms.

This work on the construction of narratives and their competition for authority and validity between social science and biomedicine is extremely important as history and as object lesson for those involved in the enterprise of the Cultural Studies of Science and Medicine (CSSM), the medical anthropological version of Science and Technology Studies (Gaines 1998; see Rodger and Steel 2016 for a volume in the new CSSM book series).

In general, Professional Lindenbaum's fine work shows us the value of tenacity in the face of more powerful authoritative voices and opening a path for us to see biomedicine, public health (as with the BSE and vCJD epidemics in Europe and AIDS in the US) as cultural practices and constructions. As well, she showed us a clear example of the workings of Fore gender, kinship, sorcery and social practices ignored by biomedical workers but which were crucial to the understanding of kuru. And, the outgrowth of that work enriched our understanding of responses and interpretations of other epidemics, including AIDS, among lay persons, health professional, politicians and anthropologists. The path she has provided is one direly needed for those who would enter shared spaces with epidemiology, biomedicine, virology, genetics, public health and the histories and philosophies of medicine.

Below, we provide a bibliography of Professor Lindenbaum's work to date. Doubtless, we can expect much more in the future from this inventive and prolific scholar.

\section{Non-Lindenbaum References Cited}

Gaines, Atwood D.

1998 From Margin to Center: From Medical Anthropology to the Cultural Studies of Science. American Anthropologist 100(1):191-198.

Prusiner, S.B.

1972 Novel Proteinaceous Infectious Particles Cause Scrapie. Science 216:136-144.

Rodger, James, and Zachary Steel

2016 Between Trauma and the Sacred. A Volume in the Cultural Studies of Science and Medicine Series. AD Gaines Editor. Cham, Switzerland: Springer International. 
Rosenberg, Charles

1992 Explaining Epidemics and Other Studies in the History of Medicine. Cambridge, UK: Cambridge University Press.

Rosenberg, Charles, and Janet Golden, eds.

1997 Framing Disease: Studies in Cultural History. New Brunswick, NJ: Rutgers University Press.

\section{Bibliography of Shirley Lindenbaum \\ Books}

Lindenbaum, Shirley

1979a Kuru Sorcery: Disease and Danger in the New Guinea Highlands. Palo Alto, CA: Mayfield.

Herdt, Gilbert, and Shirley Lindenbaum, eds.

1992 The Time of AIDS: Social Analysis, Theory and Method. Thousand Oaks, CA: Sage Publications.

Lindenbaum, Shirley, and Margaret Lock, eds.

1993 Knowledge Power and Practice: The Anthropology of Medicine and Everyday Life. Berkeley, CA: University of California Press.

Lindenbaum, Shirley

2013 Kuru Sorcery: Disease and Danger in the New Guinea Highlands, Expanded and Updated. 2nd Edition. Boulder, CO: Paradigm Publishers.

\section{Book Chapters}

Lindenbaum, Shirley, and R.M. Glasse

1971 South Fore Politics. In Politics in New Guinea. R.M. Berndt and P. Lawrence, eds. Crawley, Australia: University of Western Australia Press.

1972 Sorcery and Structure in Fore Society. In You and Others: Readings in Introductory Anthropology. A.K. Romney and P.L. DeVore, eds. Nova Scotia: Winthrop Publishers Inc.

O'Barr, Jean, S. Lindenbaum, and I. Tinker

1976a Third World Women: Factors in their Changing Status. Durham, NC: Duke University Program for International Studies.

Lindenbaum, Shirley

1976b Kuru Sorcery. In Essays on Kuru. R.W. Hornabrook, ed., pp. 28-37. Faringdon, Berks (PNG): E.W.Classey, Ltd.

1976c The Highlands of New Guinea. In Essays on Kuru. R.W. Hornabrook, ed., pp. 6-27. Faringdon, Berks (PNG): E.W.Classey, Ltd.

Lindenbaum, Shirley, and R.M. Glasse

1976d Kuru at Wanitabe. In Essays on Kuru. R.W. Hornabrook, ed., pp. 38-53. Faringdon, Berks (PNG). E.W.Classey, Ltd.

Lindenbaum, Shirley

1977 The Last Course: Nutrition and Anthropology in Asia. In Nutrition and Anthropology in Action. T. Fitzgerald, ed. Van Gorcum: Assen, Netherlands.

Lindenbaum, Shirley, and R.M. Glasse

1979b Kuru and Cannibalism. In Cultures, Curers and Contagion. N. Klein, ed. San Francisco, CA: Chandler and Sharp.

Lindenbaum, Shirley

1979c South Fore Kinship. In Blood and Semen: Kinship Systems in Highland New Guinea, V. Carrol, ed. Ann Arbor, MI: University Michigan Press.

1984 Variations on a Sociosexual Theme in Melanesia. In Ritualised Homosexuality in Melanesia. G. Herdt, ed. Berkeley, CA: University of California Press.

1986 Rice and Wheat: The Meaning of Food in Bangladesh. In Food, Society and Culture. R.S. Khare and M.J.S.A. Rao, eds. Durham, NC: Carolina Academic Press.

1987 Loaves and Fishes in Bangladesh. In Food and Evolution: Toward a Theory of Human Diets. M. Harris and E. Ross, eds. Philadelphia, PA: Temple University Press. 
1987 The Mystification of Female Labors. In Gender and Kinship Theory. J. Collier and S. Yanagisako, eds. Palo Alto, CA: Stanford University Press.

1988 The Influence of Maternal Education on Infant and Child Mortality in Bangladesh. In Selected Readings in the Cultural, Social and Behavioral Determinants of Health. J.C. Caldwell and G. Santow, eds. Canberra: Highland Press.

1989 Segments of Chapter 2, Sexual Behavior and AIDS Segments of Chapter 4, Facilitating Change in Health Behaviors. In AIDS, Sexual Behavior and Intravenous Drug Use. Washington, DC: National Academy Press.

1990 The Ecology of Kuru. In Epidemiological Perspectives on Populations in Transition. A.C. Swedlund and G. Armelagos, eds. Santa Barbara, CA: Bergin Publishers.

1990 The Education of Women and the Mortality of Children in Bangladesh. In A Political Economy Perspective. A.C. Swedlund and G. Armelagos, eds. Santa Barbara, CA: Bergin Publishers.

1990 (Segments of) AIDS: The Second Decade. Washington, DC: National Academy Press.

Lindenbaum, Shirley, and R.M. Glasse

1992 Fieldwork in the South Fore: the Process of Ethnographic Enquiry. In Prion Diseases of Humans and Animals. S. Prusiner, J. Collinge, J. Powell, and B. Anderton, eds. Hempstead, Herts, UK: Ellis Horwood.

Lindenbaum, Shirley

1992 Knowledge and Action in the Shadow of AIDS. In The Time of AIDS. G. Herdt and S. Lindenbaum, eds. Thousand Oaks, CA: Sage Publications.

1993 (Segments of) The Social Impact of AIDS in the United States. Washington, DC: National Academy Press.

1995 Sex Research After Modernity. In Conceiving Sexuality: Approaches to Sex Research in a Postmodern World. R. Parker and J. Gagnon, eds. New York: Routledge.

1997 Kuru. In History of Physical Anthropology: An Encyclopedia. F. Spencer, ed. New York: Garland Publishing Co.

1998 Images of Catastrophe. In The Political Economy of AIDS. Merrill Singer, ed. New York: Baywood Publishing Co.

2008 Foreword: Making Sense of AIDS. In Culture, Sexuality, and Power in Melanesia. Leslie Butt, and Richard Eves, eds., pp. vii-xiii. Honolulu, HI: University of Hawaii Press.

2009 Explaining Kuru: Three Ways to Think About an Epidemic. In Plagues. Epidemics and Ideas. D. Ann Herring, and Alan C. Swedlund, eds., pp. 323-344. Oxford, UK: Berg publishers.

2016 Preface: Mortuary Dialogues. In Death Ritual and the Reproduction of Moral Community in Pacific Modernities. David Lipset and Eric Silverman, eds. New York: Berghahn.

\section{Journal Publications}

Lindenbaum, Shirley

1964 The Social Effects of Kuru. Papua New Guinea Medical Journal 7:36-47. Reissued, Washington, DC: U.S. Dept. H.E.W.

1965 Attitudes to Health and Disease in East Pakistan. Technical Committee Report. Dhaka: Cholera Research Laboratory. Reissued, C.R.L. Working paper 1977.

1966 Infant Care in Rural East Pakistan. Technical Committee Report. Dhaka: Cholera Research Laboratory. Reissued C.R.L. Working Paper 1977.

1963 A Note on Fore Medicine and Society with an Ethno-botanical list. Papua New Guinea: Dept. of Public Health. Reissued, National Institutes of Health, Bethesda, Maryland.

1963 The Social Life of Women in the South Fore. Papua New Guinea: Mimeographed, Dept. of Public Health. Reissued, National Institutes of Health, Bethesda, Maryland.

1964 The Social Effects of Kuru. Papua New Guinea Medical Journal 7:36-47. Reissued, U.S. Department of Health, Education and Welfare.

Lindenbaum, Shirley, and R.M. Glasse

1967 How New Guinea Natives Reacted to a Total Eclipse. Transaction 5:46-52.

Lindenbaum, Shirley

1968 Woman and the Left Hand: Social Status and Symbolism in East Pakistan. Mankind 6:537-544. 
Mathews, J., R.M. Glasse, and S. Lindenbaum

1968 Kuru and Cannibalism. Lancet 2:449-452.

Lindenbaum, Shirley

1969 Santé et Maladie au Pakistan Oriental. Études Rurales 32:94-103.

1969 Fore Age Mates. Oceania 39:165-173.

Glasse, R.M., and S. Lindenbaum

1969 South Fore Politics. Anthropological Forum 2:308-326.

Lindenbaum, Shirley

1971 Sorcery and Structure in Fore Society. Oceania 41:277-288.

1972 Sorcerers, Ghosts and Polluting Women: an analysis of religious belief and population control. Ethnology 11(3):241-253.

1974 The Social and Economic Status of Women. Dhaka, Bangladesh: Publication of the Ford Foundation.

1975 Sorcery and Danger. Oceania 46:68-75.

1975 The Value of Women in Bengal in the C19th and C20th. J.R. McLane, ed., pp. 75-85. Michigan State University South Asia Series Occasional Paper no. 25.

1977 A Wife is the Hand of Man. In Man and Woman in the New Guinea Highlands. P. Brown, and G. Buchbinder, eds. American Anthropological Association Special Publication, no. 8.

1981a Implications for Women of Changing Marriage Transactions in Bangladesh. Studies in Family Planning 12(11):394-401.

1981b The Image of the Sorcerer in Papua New Guinea. In Sorcery and Social Change in New Guinea. M. Zelenietz, and S. Lindenbaum, eds. Social Analysis 98:119-129.

1982 Cannibalism: Symbolic Production and Consumption. In The Ethnography of Cannibalism. P. Brown and D. Tuzin, eds. Special Publication of the Society for Psychological Anthropology.

1991 Anthropology Rediscovers Sex. Social Science \& Medicine 33:865-866.

1994 Reflections on Papua New Guinea in an Australian Mirror. Identities 1:1.

2001 Kuru, Prions and Human Affairs. Thinking About Epidemics. Annual Review of Anthropology 30:363-385.

2002 Fore Narratives Through Time. Current Anthropology 43:63-74.

2004 Thinking About Cannibalism. Annual Review of Anthropology 32:475-498.

2008 A la rencontre de la personne. Cahiers Internationaux de Sociologie CXXiV, pp. 83-102.

2008 Understanding Kuru: the contribution of anthropology and medicine. Philosophical Transactions of the Royal Society B 363(1510):3715-3720.

2009 Cannibalism. Kuru and Anthropology. Folia Neuropathologica 47(2):138-144.

2012 Kuru, genes, cannibals and neuropathology. Journal of Neuropathology and Experimental Neurology 71:2(February). Liberski, Sikorska, Lindenbaum, Goldfarb, McLean, Hainfellner and Brown.

2013 Entry on Cannibalism, International Encyclopedia of the Social and Behavioral Sciences. 2nd Edition. New York/Amsterdam: Elsevier Publications.

2015 An Annotated History of Kuru. Medicine Anthropology Theory 2(1):95-128.

2016 Foreword. In Mortuary Dialogues: Death Ritual and the Reproduction of Moral Community in Pacific Modernities. David Lipset, and Eric K. Silverman, eds. New York: Berghahn.

2016 Paula Brown and Harold Brookfield: An Interdisciplinary Collaboration. Oceania, December, 2016.

2017 Anthropological Methods Used in Kuru Research. In Prion Diseases. Pawel P. Liberski, ed. Neuromethods 129, pp. 33-48. Humana Press (Electronic version - Neuromethods 129, Springer Protocols). 